\title{
Collective Competence and Systemic Thinking: An Inter-organizational Context
}

\section{Adriana Locatelli Bertolini}

\author{
Ms. Faculdade de Integração do Ensino Superior do Cone Sul (FISUL); locatelli.bertolini@gmail.com
}

Janaina Macke

Dr. Faculdade Meridional (IMED); Universidade de Caxias do Sul (UCS); janaina.macke@imed.edu.br

Patricia Wolf

PhD, Lucerne University of Applied Sciences and Arts, Future Laboratory CreaLab; patricia.wolf@hslu.ch

\section{Doi:10.5901/mjss.2016.v7n5p105}

\begin{abstract}
The collective competence is viewed as the ability of a group of individuals acting collectively towards a common goal. It is more than the sum of the individual competences, and its management asks for breaking barriers of segmented views and for understanding the importance of managing the interconnections. This study aims to identify the presence of a collective competence in the Brazilian Wine Industry. For this purpose, we collected and analyzed data through case study method, content analysis and systems thinking tools. We analyzed the data according to four elements: sensemaking, interactive action, know-how to communicate and know-how to cooperate. The systemic structure that resulted from the case analysis shows no well-established collective competence and the results show a lack of elements such as, cooperation, communication and predisposition to share knowledge and competences. This presents a situation similar to the archetype named "accidental adversaries" that is characterized by some unconnected elements. These elements may address the emergence of a collective competence.
\end{abstract}

Keywords: collective competence; inter-organizational contexts; systems thinking; Brazilian Wine Industry.

\section{Introduction}

In the field of collective competences, the recognition of both theoretical and empirical gaps is a key topic for new studies in the area (Bitencourt, 2009; Ruas et al., 2005; Sandberg, 2000). This study provides an empirical contribution on the theme of collective competence in the food SMEs context; more specifically it investigates elements that contribute to the emergence of a collective competence in a local production organization, such as the Brazilian wine industry. Both the coordination and the organization of different knowledge and viewpoints within collective projects between different organizations (Frohm, 2002), e.g. in the food SMEs context, represent a big challenge (Colurcio et al., 2012; Deiters and Schiefer, 2012).

Collective competence emerges within a team or working group (with geographical proximity or not). It is more than the sum of the individual competences, as it relates the synergy among these competences and the social interactions within the enabled group (Zarifian, 2001). The management of collective competencies asks for breaking barriers of segmented views and for understanding the importance of managing the interconnections.

To this end, the ability to manage the systemic nature of organizations and their interactions with others is essential. This ability involves the coordination of the organization itself and its specific features, i.e. the resources within the boundaries of the organization into processes of value creation. Furthermore, this skill also involves access and coordination of important organizational resources that are beyond its borders (Sanchez, 2002; Colurcio et al., 2012).

Each individual or group can address the interactive process actively or passively. In a passive way, groups assume more selfish attitudes, with almost no concern about other stakeholders. But, in a proactive attitude, the ability of local actors to overcome the contradictions and conflicts may result in local developments through the collective action of its players, whereby the community can express its greatest potential. In short, groups can simply react to events or create new ones.

This study might serve as a basis for other studies, as it will provide an empirical contribution on the analysis of 
some key elements for the emergence of a possible collective competence in the SMEs food context.

The paper is structured as follows: After a literature review and the presentation of the research context, the method section explains the sample as well as methods for data collection and data analysis. The subsequent findings section provides a descriptive overview on the thematic areas that respondents talked about in the interviews. The final section discusses the findings and concludes on the insights gained from this study.

\section{The Collective Competence Concept}

The collective competence theory can be analyzed from two different: the functional and the social. The functional perspective is the complement of the organizational competence concept, in the sense of a portfolio of knowledge, skills and attitudes at different levels, sectors and processes of the organization (Leonard-Barton, 1992; 1995; Nordhaug and Grönhaug, 1994; Puente-Palacios, 2002; Siqueira, 2002; Ruas et.al., 2005; Collin and Grasser, 2011; Michaux, 2011; Retour and Krohmer, 2011) The social perspective of collective competence is related to the set competences of groups, in developing a common knowledge base for the construction of collective meaning and sense of interdependence (cooperation) within the group (Boreham, 2004; Frohm, 2002; Hansson, 2003; Boterf, 1997; 2003; Sandberg, 2000; Weick and Roberts, 1993; Weick, 1993; Zarifian, 2001).

In this study we adopt a social approach, as it is useful to analyze the emerging of collective competence in a local production arrangement, in which the groups' performance is more relevant than the performance of isolated elements (companies).

The classification of collective competences we propose is changeable and not exclusive, indeed some of the mentioned authors focused on both the two perspectives. Although some of them adopt a functional viewpoint, they may also address the issue of groups, in a social perspective (Bonotto and Bitencourt, 2006). In other words, regardless of the adopted perspective, various definitions agree on the systemic logic approach to understand the interrelationships between different variables. This logic considers the context as a dynamic field of forces acting together to produce a systemic emerging point, where the whole is different from every part, i.e., as the collective expertise. The system has its own characteristics that may not exist in each of its constituent parts taken separately (Morin, 1991).

Time and space are also crucial in the development of collective competences. The time determines the experience or tacit knowledge in the construction of practical competence. Space is considered the most important dimension of interpersonal skills, because it is where the interaction happens. The interpersonal competence develops at a given point in time, while the practical competence evolves continuously over time. Thus, the construction of collective competences can be seen as cycles over time. In each cycle, the competence of the group becomes more developed and stronger (Bonotto and Bitencourt, 2006).

Based on the above assumptions, Frohm (2002) proposes the development of collective competences in a project context, in which the challenge is to coordinate and organize the different knowledge bases and different perspectives of the team members. In general, what happens is that each player has different opinions on how everyone should play its role in order to contribute to the achievement of the project goals. Thus, to undertake a project and to achieve the defined objectives, the team members have to give meaning to the situation.

Categories of analysis of the collective competence we defined rely on different authors (Weick and Roberts, 1993; Weick, 1993; Sandberg, 2000; Frohm, 2002; Hansson, 2003; Boterf, 2003; Boreham, 2004; Michaux, 2005), and the common issues in their theories. From their findings, we have identified four common characteristics of the collective competence: sensemaking, interactive action, know-how to communicate, know-how to cooperate and the sense of interdependence (figure 1).

\begin{tabular}{|l|l|}
\hline Collective Competence Dimension & Elements of each dimension \\
\hline $\begin{array}{l}\text { Sensemaking } \\
\text { Weick and Roberts (1993), Frohm (2002), Hansson } \\
(2003), \text { Weick (1993), Boreham (2004), Sandberg } \\
(2000)\end{array}$ & $\begin{array}{l}\text { Ability to give meaning to the actions of other individuals, guided more by what is } \\
\text { reasonable rather than by accuracy. } \\
\text { Ability to adapt a current action considering the events reported by respondents. } \\
\text { Number of meetings among entities; number of projects developed jointly. }\end{array}$ \\
\hline $\begin{array}{l}\text { Interactive Action } \\
\text { Hansson (2003), Frohm (2002), Michaux (2005), } \\
\text { Sandberg (2000) }\end{array}$ & $\begin{array}{l}\text { Joint actions of representative members of different entities undertaken in a } \\
\text { reflective and interactive way. } \\
\text { Experience sharing that comes from a collective reflection, based on continuous } \\
\text { improvement and driven by experience. This sharing can be explicit or not. }\end{array}$ \\
\hline $\begin{array}{l}\text { Know-how to Communicate } \\
\text { Boterf (2003), Michaux (2005), Boreham (2004) }\end{array}$ & $\begin{array}{l}\text { Common and/or specific language of a group. Knowing-how to communicate } \\
\text { enables teams to talk "with half-measures", "read between the lines", without } \\
\text { extra comments and explanations. } \\
\text { It is necessary to know-how to communicate quickly to "know what to do" and }\end{array}$ \\
\hline
\end{tabular}




\begin{tabular}{|l|l|}
\hline & what to do "in time". \\
\hline Know-how to Cooperate and Sense of & Sharing knowledge for joint action. \\
Interdependence & Mutual daily aid, which implies knowing to respect the different points of view. \\
Boterf (2003), Michaux (2005), Boreham (2004) & $\begin{array}{l}\text { Recognition of the differences among the groups; promoting negotiation } \\
\text { processes and alliances. }\end{array}$ \\
\hline
\end{tabular}

Figure 1 - Collective competence dimensions and elements of analysis

Collective competences are a network and systemic competence, in which each individual/entity needs the contribution of the others, in an environment that indicates all the people with whom the individual/entity communicates and cooperates to perform a task. The collective competence evolves through pragmatic orders and combinations (Michaux, 2005).

The system thinking is a useful approach for understanding the collective competences. It focuses both on the interrelationships and on the restructuring of the way of thinking to evaluate patterns of behavior and shared mental models (Senge, 2000; Andrade and Kasper, 1997; Jupp, 2006).

\section{The Research Context: Brazilian Wine Industry}

The Brazilian wine and sparkling wine production handles US\$ 1.3 billion based on the amounts paid by the final consumer (date from 2010). Brazil is currently the $13^{\text {th }}$ largest producer of wine (FAO, 2012; Mello, 2013). Moreover, it is considered one of the best regions in the world for growing grapes for sparkling wine production. Brazil has a consumption of 1.8 liters/per capita/year, which is in contrast to countries with a tradition of wine consumption where consumption is 40 liters/per capita/year. Imported wines represent $80 \%$ of wine consumption in Brazil (Wines of Brazil, 2014).

The Serra Gaúcha region belongs to the largest viticultural region in Brazil, with approximately 40,000 hectares of vineyards. This food network includes small viticulture properties little mechanized due to irregular topography, where the use of manpower of families predominates. This region has been growing as a producer of quality wines (Fensterseifer, 2007, Macke 2012).

The Vale dos Vinhedos region, into Serra Gaúcha, is the first Brazilian region certified with the Indication of Provenance (IPVV) in 2002 and Designation of Origin (DO) in 2012. It is one of the main oeno-touristic destinations in America and the principal Brazilian wine tourism destination. The regional certification process and the consequent creation of brands, allows the regions to become "exclusive" in the production of certain products and become a tourism hub.

In this context, the DOs are part of the global movement of market segmentation, valuing land resources. (Vieira et al, 2010). Thus, the DO should be thought as a harmonious occupation framework of cultural space, combining the promotion of a typical product and its historical and cultural aspects, biodiversity conservation and rural development (MAPA, 2014).

The selection of the Serra Gaúcha region as context of analysis satisfies the need to combine common interests with cooperation for developing collective competences. Indeed, historically, the Brazilian wine industry has been collectively developed, through closer relations between family members and friends who had similar habits and behaviors, which restricted the relationship to a limited group and not expanding to other groups (Carolis and Saparito, 2006; Macke et. al., 2012). This development model relies on the strong cultural ties and on the community spirit that is proper of immigrant families (Macke et. al., 2013). Although the existence of strong relationships and the mutual support between family living in close contexts, the process of sharing experience and information among the wine companies is complex and hard to be managed. Furthermore, the need to expand the horizontal links with outside groups (Carolis and Saparito, 2006), which is vital for developing joint projects and improving the competitiveness of the region, can make the sharing process more complicated.

\section{Research Method: Using the System Thinking to Understand Collective Competence}

This study has been developed through a qualitative research approach, as it allows researchers to understand a specific phenomenon in depth. Qualitative research is more participatory and therefore less controllable, since participants can direct the course of their interactions with the researcher. Still, in the present study, it is the most appropriate for understanding the phenomena from the standpoint of the participants and for standing our interpretation of the phenomena studied (Yin, 2009; Bardin, 2010). 


\subsection{Sample}

In qualitative research, the number of respondents must consider the criterion of representativeness of the sampling because it is not numeric as in quantitative research. This number should not be too big, but it must be sufficient to allow the researcher to be able to know well about the object of the study (Minayo, 1999). The number of people interviewed must allow repetition of information or data saturation, a situation that occurred when no new information is added to the continuity of the research process. In fact, in qualitative studies there is a need for greater depth and width of understanding.

For this study the interviewees' selection process was based on two criteria: (a) participants should belong to one of the most representative entities in Brazilian Wine Industry; (b) they should also have a strategic role in these entities. Finally, 12 members from seven representative Brazilian wine institutions have been selected (Figure 2).

\begin{tabular}{|c|l|l|}
\hline Interviewee & Entity & Role \\
\hline A & Associação Brasileira de Enologia (Brazilian Enology Association - ABE) & President \\
\hline B & Instituto Brasileiro do Vinho (Brazilian Wine Institute - IBRAVIN) & Market manager \\
\hline C & União Brasileira de Vitivinicultura (Brazilian Union of Viticulture - UVIBRA) & Counselor \\
\hline D & União Brasileira de Vitivinicultura (Brazilian Union of Viticulture - UVIBRA) & President \\
\hline E & Aprovale & Director \\
\hline F & União Brasileira de Vitivinicultura (Brazilian Union of Viticulture - UVIBRA) & Director \\
\hline G & $\begin{array}{l}\text { Associação dos Produtores de Vinhos Fino do Vale dos Vinhedos (Association of Producers of Fine } \\
\text { Wines from Vale dos Vinhedos - APROVALE) }\end{array}$ & Ex-president \\
\hline H & Instituto Brasileiro do Vinho (Brazilian Wine Institute - IBRAVIN) & President \\
\hline I & Empresa Brasileira de Pesquisa Agropecuária (Brazilian Agricultural Research Corporation - EMBRAPA) & Researcher \\
\hline J & $\begin{array}{l}\text { Associação dos Produtores de Vinhos Fino do Vale dos Vinhedos (Association of Producers of Fine } \\
\text { Wines from Vale dos Vinhedos - APROVALE) }\end{array}$ & President \\
\hline K & $\begin{array}{l}\text { Federação das Cooperativas Vinícolas do Estado do Rio Grande do Sul (Federation of the Winery } \\
\text { Cooperatives of Rio Grande do Sul State - FECOVINHO) }\end{array}$ & President \\
\hline L & Associação Gaúcha de Vinicultores (Association of Wine Producers - AGAVI) & Director \\
\hline
\end{tabular}

Figure 2 - Sample

\subsection{Data Collection}

According to the purpose of the study data have been collected through semi-structured interviews. This approach allows researchers to explore in-depth a respondent's experiences and opinions (Yin, 2009). This characteristic fits with the study because it enables the interviewer to obtain descriptions, nuances and details (Flick, 2009).

The interview guideline was built up based on the theoretical background and tested in a pre-test interview session, from which minor adjustments in the order of questions and the construction of questions were made. We developed the interview structure according to Wolf et al. (2014) that focused on collaborative networks in a different context. Figure 3 shows the main topics of the interview guideline.

\begin{tabular}{|l|l|l|}
\hline Phase & Topics & Details \\
\hline Beginning & Introduction interviewer & Personal information \\
\cline { 2 - 3 } & Information about the study & Aim of the study \\
\cline { 2 - 3 } & $\begin{array}{l}\text { Personal informational about } \\
\text { interviewee }\end{array}$ & Name/ Age / Winery / Occupation \\
\hline $\begin{array}{l}\text { Main } \\
\text { questions }\end{array}$ & Topic 1 (T1) - Sensemaking & $\begin{array}{l}\text { Are there meetings in order to give feedback to the associates? } \\
\text { Are there training programs for the associated wineries? How do these programs } \\
\text { work? }\end{array}$ \\
\cline { 2 - 3 } & $\begin{array}{l}\text { Topic 2 (T2) - Interactive } \\
\text { action }\end{array}$ & $\begin{array}{l}\text { Are there documents where the experiences, knowledge, values and principles are } \\
\text { registered? (by documents we understand as the references of cooperation, } \\
\text { procedures, professional practices and maps of knowledge and skills) } \\
\text { Do people feel free to test new ideas, take risks and evaluate the results? }\end{array}$ \\
\cline { 2 - 3 } & $\begin{array}{l}\text { Topic 3 (T3) - Know-how to } \\
\text { communicate }\end{array}$ & $\begin{array}{l}\text { Is it possible to note the existence of a proper language among the members of the } \\
\text { wineries? }\end{array}$ \\
\cline { 2 - 3 } & $\begin{array}{l}\text { Topic 4 (T4) - Know-how to to } \\
\text { cooperate }\end{array}$ & $\begin{array}{l}\text { What do you think about this statement: "People are more intelligent together than } \\
\text { isolated. If you want something done well, ask a team instead of asking one person }\end{array}$ \\
\hline
\end{tabular}




\begin{tabular}{|l|l|l|}
\hline & & to do it on his/her own." \\
\hline Ending & Leading out & $\begin{array}{l}\text { Thanking for contribution } \\
\text { Suggestions and comments }\end{array}$ \\
\hline
\end{tabular}

Figure 3 - Interview structure (adapted from Wolf et al, 2014).

The interviews were conducted according to the storytelling technique, seeking to achieve the complexity of the context analysis. Storytelling is a search tool that aims to study and record events, life histories, trajectories of organizations, in short, historical and contemporary issues (Tomkins, 2009).

Face to face interviews were recorded and transcribed ad verbatim to provide further analysis and formal documents. The average length of the interviews was 57 minutes. Transcriptions comprise 187 pages.

\subsection{Data Analysis}

To analyze data we chose the content analysis. According to Bardin (2010), the content analysis comprises a set of communication analysis techniques to obtain, through systematic procedures and description of the objectives of message content, indicators that allow knowledge inference from the communication processes. We applied deductive coding using the following codes that we derived from our literature research: sensemaking, interactive action, know-how to communicate and know-how to cooperate.

The content analysis was developed into three stages: pre-analysis (organization of data according to categories of analysis); results processing (data analysis using the theoretical framework); and inference and interpretation (interviews clippings putting into context units) (Bardin, 2010). The results of the analysis are discussed below.

\section{The Emerging of a Collective Competence: Main Elements}

In this section we present the main results of the research, according to the following four elements: sensemaking, interactive action, know-how to communicate and know-how to cooperate. At the end, these results are summarized in a systems thinking map.

\subsection{Sensemaking}

The sensemaking process happens through interaction - when the group discusses and decides what to do - and through the inter-relationship when the individual returns to his daily tasks and stablishes links with his/her experiences determining how to do (FROHM, 2002).

This study addresses three main elements of the sensemaking. The first, is the ability to make sense of the actions of other individuals; the second, is the adaptability of an action considering the information given by the participants and third, the number of meetings and projects developed jointly by the entities (Weick and Roberts, 1993; Frohm, 2002; Hansson 2003; Weick, 1993; Boreham 2004; Sanberg, 2000).

The ability to give meaning to the actions of other individuals does not often happen, because many decisions are made within organizations without discussion with the large group (winery associations). Instead of talking openly in meetings, one respondent indicates that: "we work very isolated, too full of secrets and disputes sometimes" (interviewee E). This attitude prevents the group interaction, decreases their contributions and the inter-related activities, and thus the development of the region.

Moving on the adaptability of an action, there is a difficulty to adapt and to share the information, since there is no discussion with the large group. Indeed as showed by the following statement: "there are political problems in the organizations... very strong problems, how you'll get there in a meeting and speak openly and freely? They can even hear you, but will not take action to solve the problem" (interviewee G).

Finally, the focus on the number of meetings and projects jointly developed by different entities, Frohm (2002) highlights the importance of these meetings to encourage and develop collective skills. These meetings serve as an arena for the processes of sensemaking and coordination of different knowledge bases of individuals. The meetings (virtual or face to face) stimulate the process of collective sensemaking through the joint expertise of participants. Reveals that the respondents have monthly meetings with all members and working groups, every 15 days. However, in most cases, it does not encourage the articulation of knowledge of the participants and the discussion of problems and difficulties of the sector. "We do not speak about the problems and difficulties that exist (...)" (interviewee I). It's all a 
question of adapting people by force and not by democracy, in order to solve the problems of the entity" (interviewee B).

In the matter of joint projects, the Wines of Brazil stood out, with meetings with all members and decisions taken as a whole. At meetings of this project there seems to be greater stimulation of the sharing of difficulties and bringing out doubts, with links between the knowledge of each participant. This favors the inter-relationships when the associates apply the knowledge to their day-to-day activities and relate the context with their experiences. In this case, as an export project, it affects and changes how the wineries operate also in the domestic market.

This interrelation of what is discussed and done in the project Wines of Brazil is brought to the daily life of local wineries. This is possible to observe when they participate in important trade fairs. This was not seen before the experience of joint fairs abroad. We could see that through comments like: "The Wines [project Wines from Brazil] was a learning collective work, good for many wineries, which somehow used to compare themselves, keeping a certain distance with an air of mistrust" (interviewee I).

\subsection{Interactive Action}

Since the development of a collective competence is simultaneous for the development of a consciousness of the time and space perceived by group members, the group learns how to interact with each other and share actions and process flows, through experiences sharing (Weick and Roberts, 1993; Hansson, 2003; Frohm, 2002).

Considering the interactive action dimension two elements were included to compose the category: the actions that individuals from different entities experienced together, and the sharing of experience that comes from a collective reflection.

We can observe that the interactive action occurs, when the individuals break the barriers of formal meetings and decide to establish informal and closer relations, for example, when they organize dinners and social events in order to celebrate together. "A short time ago, we used to fight to increase the minimum price of the grape (...) this generated an uncomfortable feeling (...). Even the government used to say: 'People from the wine sector just want to fight'. Therefore, we started to sit down together once a week, have dinner and drink some wine (...) and things slowly changed" (interviewee D).

This simple change enabled the authorities to re-establish the conversation and to promote sectorial actions in the domestic market. Nevertheless, this new behavior still belongs to a small group, considering the wine chain production.

The sharing of experiences based on continuous improvement, often does not happen in the sector, indeed as pointed out by some interviewers: "people still get a little embarrassed, have some fear of speaking in a meeting or using a model from another company (...) they are afraid of saying "This is cool, it worked here, let's try it" (interviewee A). This lack hinders the learning made through experiences and the ability to develop further action that could arise by the experience of the sector.

\subsection{Know-how to Communicate}

In the wine industry we realize the difficulty of knowing how to communicate, especially with the farmers: "There is a lack of communication. The seller of pesticides [...] goes there and speaks the language of the farmers and we [wineries representants] do not" (interviewee $\mathrm{H}$ ). Another interviewee states: "There is a language barrier between the sector and the farmers, which makes it difficult to unify the vision and line of work" (interviewee L).

According to respondents, there is also an inherent difficulty of communication between the fine and regular wine producers, and the grape juice producers, which becomes an obstacle to the development of know-how and what to do in time.

\subsection{Know-how to Cooperate and Sense of Interdependence}

Know-how to cooperate is a decisive factor in the collective competence, as an assumption of collaboration between team members with norms, cultures, resources, or different cognitive procedures. The consequence for a system of interrelated activities is that individuals can work with, for or against others.

Considering the know-how to cooperate and sense of interdependence dimension we found three elements: knowledge sharing; daily mutual aid and negotiation and alliances.

The analysis of the wine industry showed that there are no relevant forms of cooperation among wineries on the domestic market. However, in foreign markets, through the project Wines of Brazil, the cooperation process appeared in $60 \%$ of the interviews. Considering the domestic market, the lack of agreement among members into an association, the 
difficulty to reach a reasonable cooperation level and the barriers imposed from the "elders" were the most cited elements. The analysis of the interviews indicates that there is a great difference in the opinions according to the generation. The elders see the industry with more attention in relation to information and experiences sharing. Most young people believe they can work with the sector and facilitate the relationship of working together to take part in decision-making, being more altruistic: "the elders are being put aside... young people are assuming responsibilities with clearer and wider views, less prejudiced and individualistic (...)"(interviewee F).

In addition, an increasing number of young people are taking strategic areas not only in wineries, but also in the associations, as highlighted by the following statement: "I hope that as young people are taking care of their wineries, they will have a different view and change their minds and if they act together, they will get stronger" (interviewee J). Perhaps, this is a sign of improving relations in the wine industry, through the recognition of the interdependence among groups, the need of promoting alliances and the perception of the importance of collective oriented decision-making.

On daily relations, the associations face some interpersonal problems such as the members availability to listen to another point of view and in to be involved in sharing experiences and best practices. At the same time, the wineries want to take the advantages of belonging to an association (especially because of the Origin Denomination demands); the majority of the members still consider the others as competitors instead of partners. In fact, they are afraid of sharing knowledge and experiences, because in most cases the winery competence is something easy to copy and to overtake. This opportunistic behavior prevents the emerging of a collective competence, because the development of a collective competence requires the existence of a sensemaking, interactive action, know-how to communicate and know-how to cooperate, as we detailed above. In order to summarize our findings, we built the systemic thinking map that shows the interrelationship between the variables we proposed (figure 4).

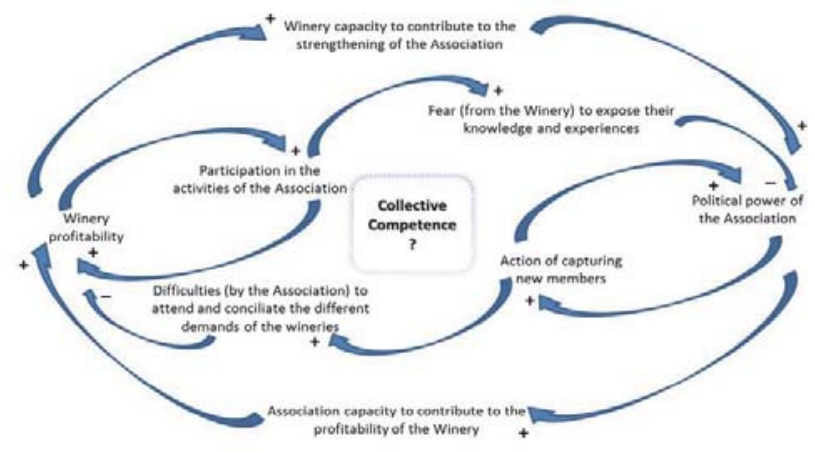

Figure 4 - Systemic thinking map for collective competence development in the Brazilian Wine Industry

The signs on the map indicate the nature of the relation: "plus" means that the two variables go to the same direction (when one increases, the other increases too), whereas "minus" indicates that when one variable increases, the other decreases, and vice versa.

To increase profitability (and also, to obtain the advantages of Denomination of Origin), the wineries decide to participate on the association (left side of the map). This brings several opportunities, including the chance of selling the wines in the international market (under the label of Wines of Brazil). On the extreme right of the map, the association goes in the same direction: to improve success, the association wants to attract more members. However these actions, taken isolated, seem to make sense, they produce negative effects that can be seen only in a systemic way.

Therefore, the winery participation on the association also brings a fear of sharing their experiences and best practices with the partners which reduces the political power of the association. In the same way, the increasing number of members brings difficulties to conciliate the growing number of demands by the wineries. What supposed to be a good choice for an agent is too harmful for the collectivity.

This systemic thinking map is inspired by the archetype named accidental adversaries (Senge, 2000). This structure is an example of how the myopic local activity (with the best of intentions) can undermine an effort of interorganizational cooperation. 


\section{Final Remarks}

The collective competence is associated with various levels of complexity, (especially in an inter-organizational context when the number of actors involved is significant) due to the fact that often there is neither a common knowledge base accessible to all members, and nor the concern of a sensemaking and cooperation building. This endogenous predisposition for sharing and cooperation can facilitate the leveraging of collective competence, but should be a deliberate effort on the part of the system components. Our results emphasize the lack of elements such as, cooperation, communication and pre-disposition to share knowledge and competences.

The development of isolated competences does not create synergy, generating lower benefits for the industry. The lack of this sense of interdependence and the difficulty of communication, showed in the systemic thinking map, jeopardizes the development of a collective competence.

The competences available in the Brazilian Wine Industry are at the organizational level, i.e., have failed to overcome the barriers of the organization, in order to reach the inter-organizational level. From this perspective, both the collective associations, and organizations influence and modify the behavior of others, although this movement can be considered too weak.

However, we realize that in the case of the Brazilian Wine Industry, the Wines of Brazil project could represent a new movement in order to develop a memory of the collective action and the concern to share with all members new experiences.

Finally, it is important to highlight that the competences may be more or less visible, depending on how often they are put into action. When competences are not identified, they have little or no immediate value to the collectivity, but once detected, the competences constitute a major potential for the development of a sector.

\section{Acknowledgements}

This work is being supported by the Faculty Meridional (Faculdade Meridional - IMED) the University of Caxias do Sul (Universidade de Caxias do Sul - UCS), the Lucerne University of Applied Sciences and Arts, the Faculty FISUL (Faculdade FISUL), the National Counsel for Scientific and Technological Development (Conselho Nacional de Desenvolvimento Científico e Tecnológico - CNPq) and the Coordination for the Improvement of Higher Education Personnel (Coordenação de Aperfeiçoamento do Pessoal de Nível Superior - Capes).

\section{References}

Andrade, A. L., Kasper, H. (1997). Pensamento sistêmico e modelagem computacional: aplicação prática na empresa de trens urbanos de Porto Alegre. Paper presented at the XVII Encontro Nacional de Engenharia de Produção (ENEGEP), Porto Alegre, Brasil.

Bardin, L. (2010). Análise de conteúdo. Lisboa: Edições 70.

Bitencourt, C. A. (2009). Gestão por Competências: Uma analise da mobilização entre competências, capacidades e recursos. Revista Brasileira de Docência, Ensino e Pesquisa em Administração 1 (1) 126-136.

Bonotto, F., Bitencourt, C. (2006). Os elementos das competências coletivas em grupos de trabalho: a experiência da Copesul. Paper presented at the XXX Encontro Nacional dos Programas de Pós-graduação em Administração (EnANPAD), Salvador, Brasil.

Boreham, N. (2004). A theory of collective competence: challenging the neo-liberal individualisation of performance at work. British Journal of Educational Studies 52 (1) 5-17.

Boterf, G. (1997). Construire la Compétence Collective de L'entreprise. Gestion 22 (3) 82-85.

Boterf, G. (2003). Desenvolvendo a Competência dos Profissionais. Porto Alegre, Artmed.

Carolis, D. M.; Saparito, P. (2006). Social capital, cognition, and entrepreneurial opportunities: A theoretical framework. Entrepreneurship Theory and Practice 30 (1) 41-56.

Collin T., Grasser B. (2011). Das Competências Individuais à Competência Coletiva: Contribuições da Aprendizagem em um Serviço de Emergência Hospitalar. In Retour D. et al. (Ed.), Competências coletivas: no limiar da estratégia. (pp. 79-98). Porto Alegre: Bookman.

Colurcio, M., Kocher, P.-Y., Wolf, P.,and Russo Spena, T.(2012). Asymmetric relationships in networked food innovation processes. British Food Journal, 114(5), pp. 702-727.

Deiters, J., Schiefer, G. (2012). Network Learning and Innovation in SME Formal Networks. International Journal on Food System Dynamics 3 (3) 201-213.

Fensterseifer, J. E. (2007). The Emerging Brazilian Wine Industry. International Journal of Wine Business Research 19 (3) 187-206.

Flick, U. (2009). An introduction to qualitative research. (4th ed.). London: Sage.

Frohm, C. (2002). Collective competence in an interdisciplinary project context. Unpublished master dissertation, International Graduate School of Management and Industrial Engineering, Linköping, Sweden. 
Hansson, H. (2003). Kolektiv kompetens. Unpublished doctoral dissertation, Götemborg University, Sweden.

IBRAVIN, Instituto Brasileiro do Vinho. (2005). Visão 2025: Programa de Desenvolvimento Estratégico do Setor Vitivinícola do Rio Grande do Sul. Unpublished document, Bento Gonçalves, RS, Brasil.

Jupp, V. (ed.) (2006). The SAGE dictionary of social research methods. London: SAGE Publications.

Leonard-Barton, D. (1992). Core capabilities and core rigidities: a paradox in managing new product development. Strategic Management Journal 13 (S1) 111-125.

Leonard-Barton, D. (1995). Wellsprings of knowledge: building and sustaining the sources of innovation. Boston: Harvard Business School Press.

Macke, J., Genari, D., Faccin, K. (2012). Social Capital in Brazilian Wine Industry Networks. African Journal of Business Management 6 (19) 5990-5998.

Macke, J., Vallejos, R. V., Faccin, K., Genari, D. (2013). Social Capital in Collaborative Networks Competitiveness: the case of the Brazilian Wine Industry Cluster. International Journal of Computer Integrated Manufacturing 26 (1-2) 117-124.

MAPA. (2014). Ministério da Agricultura, Pecuária e Abastecimento. [Online] Available: http://www.agricultura.gov.brl (28 feb, 2014)

Mello, L. M. R. (2012). Vitivinicultura mundial: principais países e posição do Brasil. Comunicado Técnico, Bento Gonçalves: EMBRAPA, n. 121. [Online] Available: http://www.cnpuv.embrapa.br/publica/comunicado/cot121.pdf

Michaux V. (2011). Articular as Competências Individual, Coletiva, Organizacional e Estratégica: Esclarecendo a Teoria dos Recursos e do Capital Social. In Retour D. et al. (Ed.), Competências coletivas: no limiar da estratégia (pp 1-21.). Porto Alegre: Bookman.

Michaux, V. (2005). Compétences collectives et haute performance: apports théoriques et enjeux opérationnels. Revue de Gestion des Ressources Humaines 58 (1) 45-66.

Morin, E. (1991). Introdução ao Pensamento Complexo. Lisboa: Instituto Piaget.

Nordhaug, O., Grönhaug, K. (1994). Competences as resources in firms. The International Journal of Human Resource Management 5 (1) 89-106.

OIV (Organization Internacionale De La Vigne Et Du Vin). (2010). Elements de conjocture vitivinicle mondiale. Paris: OIV.

Puente-Palacios, K. E. (2002). Depender ou não depender, eis a questão: um estudo multinivel do efeito de padrões de interdependência na satisfação dos membros das equipes de trabalho. Unpublished doctoral dissertation, Universidade de Brasília, Brasília, DF, Brasil.

Retour D.; Krohmer C. A. (2011). Competência Coletiva: Uma Relação-Chave na Gestão das Competências In Retour D. et al. (Ed.), Competências coletivas: no limiar da estratégia. (pp. 45-78). Porto Alegre: Bookman.

Ruas, R., Antonello, C., Boff, L. (2005). Os novos horizontes da gestão e aprendizagem organizacional e competências. Porto Alegre: Bookman.

Sanchez, R. (2002). Understanding competence-based management: identifying and managing five modes of competence. Journal of Business Research 57 (5) 518- 532.

Sandberg, J. (2000). Understanding human competence at work: an interpretive approach. The Academy of Management 43 (1) 9-25.

Senge, P. (2000). A Quinta Disciplina. (7a ed.). São Paulo: Editora Best Seller.

Siqueira, M. (2002). Medidas do comportamento organizacional. Estudos de Psicologia 7 (SI) 11-18.

Tomkins, A. (2009) "It was a great day when......." an exploratory case study of reflective learning through storytelling. Journal of Hospitality, Leisure, Sport and Tourism Education 8 (2) 123-131.

Vieira, A.C.P., Watanabe, M., Bruch, K.L. (2012). Perspectivas de desenvolvimento da vitivinicultura em face do reconhecimento da Indicação de Procedência dos Vales da Uva Goethe. Revista GEINTEC, 2 (4) 327-343.

Weick, K. (1993). The collapse of sensemaking in organization: the man gulch disaster. Administrative Science Quarterly 38 (4) 628-652.

Weick, K., Roberts, K. (1993). Collective mind in organizations: heedful interrelating on flight decks. Administrative Science Quarterly 38 (3) $357-381$.

Wines of Brazil (2014). Brazilian Wine History. Bento Gonçalves, IBRAVIN. [Online] Available: http://www.winesofbrasil.com/Check Option.aspx

Wolf, P., Troxler, p., Kocher, P-Y., Harboe, J., Gaudenz, U. (2014). Sharing is Sparing: Open Knowledge Sharing in Fab Labs. Journal of Peer Production 5 (1) 1-11.

Yin, R. K. (2009). Case study research: Design and methods. (4th ed.). Thousand Oaks: Sage.

Zarifian, P. (2001). Objetivo Competência: por uma nova lógica. São Paulo: Atlas. 